\title{
Politics of Race: Diskriminasi Rasial Etnis Tionghoa dalam Kebijakan Pertanahan di Daerah Istimewa Yogyakarta
}

\author{
Felisitas Friska Dianing Puspa ${ }^{1}$, Fira Salzabilla \\ Puspita Sari², Finna Azarine Lathifah³, Johanes Nadimje- \\ thro" ${ }^{4}$ Agus Wahyu Nugroho ${ }^{5}$, Ahmad Nurcholis ${ }^{6}$
}

\begin{abstract}
Abstrak
Tulisan ini berusaha memberikan elaborasi mengenai faktor-faktor apa saja yang berperan dalam melanggengkan diskriminasi hak kepemilikan tanah terhadap penduduk etnis Tionghoa di wilayah Yogyakarta. Terdapat keunikan dalam implementasi Undang-Undang Pokok Agraria, di Kota Yogyakarta dengan Sultan sebagai pusat kekuasaannya. Dari penelusuran historis terdapat serangkaian tindakan diskriminatif terhadap penduduk etnis Tionghoa berkaitan dengan hak kepemilikan tanah. Mulai dari kesulitan mendapatkan pengakuan sebagaiwarganegara Indonesia, penetapan status yang didasarkan pada ciri-ciri rasial, hingga penolakan kepemilikan tanah dari aturan formal yang berlaku beserta birokrasi yang berkuasa. Berbeda dengan wilayah lainnya di Indonesia, Yogyakarta dengan segala tradisinya

1 Penulis adalah mahasiswa program sarjana Departemen Politik dan Pemerintahan Universitas Gadjah Mada.

2 Penulis adalah mahasiswa program sarjana Departemen Politik dan Pemerintahan Universitas Gadjah Mada.

3 Penulis adalah mahasiswa program sarjana Departemen Politik dan Pemerintahan Universitas Gadjah Mada.

4 Penulis adalah mahasiswa program sarjana Departemen Politik dan Pemerintahan Universitas Gadjah Mada.

5 Penulis adalah mahasiswa program sarjana Departemen Politik dan Pemerintahan Universitas Gadjah Mada.

6 Penulis adalah mahasiswa program sarjana Departemen Politik dan Pemerintahan Universitas Gadjah Mada.
\end{abstract}


masih mempertahankan diskriminasi rasial tersebut. Dalam praktiknya di masa kini, diskriminasi tersebut, selain tercantum dalam aturan formal, juga terinstitusionalisasi pada pemahaman masyarakat Yogyakarta, sehingga menjadi sesuatu yang normal. Proses institusionalisasi tersebut dapat dikaitkan dengan pengaruh politik kekuasaan yang dimiliki oleh Sultan terhadap seluruh lapisan masyarakat Yogyakarta, berikut lembagalembaga formal terkait. Melalui studi lapangan serta sumber-sumber sekunder, tulisan ini menjelaskan apa yang menyebabkan diskriminasi tersebut dapat bertahan dari waktu ke waktu, baik dari sisi aturan formal, historis serta pemahaman sosiokultural yang memperkuatnya.

Kata kunci: Diskriminasi; Etnis Tionghoa; Hak Kepemilikan Tanah; Sultan

\section{PENDAHULUAN}

Dinamika agraria di Indonesia tak pernah lepas dari konflik dan polemik yang senantiasa mengikutinya. Pemberlakuan Undang-Undang Pokok Agraria (UU PA) Tahun 1960 sejatinya dimaksudkan sebagai jembatan untuk mewujudkan keadilan sosial dalam aspek agraria bagi rakyat Indonesia. Melalui pemberlakuan UU PA tersebut, terjadi perubahan yang cukup signifikan terhadap cara pandang dan tata kelola suatu negara atas tanahnya.

Sebelumnya, pengelolaan tanah oleh negara yang didasarkan pada konsep asas domein negara era Kolonial memegang prinsip sesuai asas tersebut, yaitu bahwa seluruh tanah yang tidak memiliki status kepemilikan yang tidak sesuai dengan hukum Barat 
secara otomatis akan dianggap sebagai milik negara (Rachman, 2012). Dengan demikian, sebagaimana dinyatakan oleh Rachman, hal ini membuat para kelas kapitalis dan para pemegang modal (terutama dari pihak Eropa) lebih diuntungkan karena dibukakan jalan untuk berinvestasi dengan adanya konsep tersebut. Sementara melalui konsep Hak Milik Negara (HMN), pengelolaan tanah oleh negara didasarkan pada Pancasila sebagai dasar negara Republik Indonesia, sehingga lebih mengedepankan kebutuhan seluruh rakyat Indonesia dalam pelaksanaannya, selain untuk mengatasi berbagai permasalahan agraria yang timbul selama era Kolonialisme (Rachman, 2011).

Sebagaimana dikemukakan di atas, UU PA diberlakukan sebagai jalan keluar bagi bermacam konflik ketidakadilan agraria yang dialami oleh rakyat Indonesia (terutama dari kelas-kelas menengah ke bawah) di bawah penguasa Kolonial. Salah satu permasalahan yang menjadi target adalah konsep pengelolaan tanah secara feodal yang diberlakukan oleh wilayah pemerintahan otonom Kasultanan di Surakarta dan Yogyakarta (Rachman, 2011). Sebagaimana tercatat bahwa wilayah tersebut memegang status sebagai swapraja dengan kontrak panjang (lange contracten) khusus dengan negara Kolonial, pengelolaan tanah di 
wilayah tersebut menggunakan hak konversi sebagai prinsip hukum agrarianya. Prinsip ini mengemukakan bahwa Kesultanan Yogyakarta dan Surakarta masingmasing memberikan konsesi tanah berjangka waktu 50 tahun kepada perkebunan-perkebunan milik orang Eropa, yang dibayarkan secara berkala oleh para pemilik perkebunan kepada raja (Gautama \& Harsono, 1972). Keberadaan prinsip ini menyebabkan ketimpangan agraria terutama kepada para petani lokal dikarenakan tidak mendapatkan distribusi tanah untuk dikelola. Setelah UU PA diberlakukan, tanah-tanah perkebunan yang sebelumnya dimiliki oleh orang Eropa dibagikan kepada para petani yang tinggal di wilayah tersebut (Rachman, 2012).

Namun, praktik implementasi UU PA di wilayah Kasultanan Yogyakarta menemukan hambatan baru, yaitu diskriminasi rasial. Tercatat sejak era proklamasi hingga dekade 2010-an, konflik agraria di wilayah Yogyakarta diwarnai dengan kasus-kasus diskriminasi yang diarahkan kepada para penduduk dengan latar belakang etnis Tionghoa. Adapun faktor utama yang menjadi garis besar dari penyebab diskriminasi tersebut dapat diidentifikasi sebagai hasil dari stigma historis yang menempel pada era penduduk etnis Tionghoa. Pertama, adanya stigma bahwa mereka 
merupakan kelompok yang memihak Belanda bahkan setelah Proklamasi kemerdekaan Indonesia dan ingin meninggalkan wilayah Yogyakarta dikarenakan pandangan mereka bahwa Sultan adalah orang yang proRepublik Indonesia (Kurniadi, 2019). Kedua, adanya pertimbangan yang bersifat ekonomi seperti redistribusi kekayaan terhadap penduduk "pribumi" (upaya mempersempit wealth gap), serta upaya pemerintah Yogyakarta untuk memungut biaya tambahan dari kekayaan mereka.

Dalam perkembangannya, diskriminasi tersebut berkisar dalam bentuk penolakan terhadap hak kepemilikan tanah khusus kepada penduduk etnis Tionghoa, sebagaimana tercantum dalam kodifikasi hukum Instruksi Wakil Gubernur Tahun 1975 mengenai Penyeragaman Policy Pemberian Hak Atas Tanah kepada Seorang WNI Non-Pribumi (Kurniadi, 2019). Pun sebelum surat instruksi tersebut diberlakukan, penduduk etnis Tionghoa juga telah mengalami serangkaian kesulitan mengenai pengakomodiran hak kepemilikan tanah bagi mereka. Hal ini tercermin dari beberapa fakta kebijakan historis seperti pelarangan alih kepemilikan tanah dari penduduk pribumi ke non-pribumi oleh pihak Kolonial Belanda (Vervreemdingsverbod) di tahun 1875 , serta pelarangan 
serupa yang dikeluarkan oleh Kesultanan di tahun 1918 (Rijksblad) yang bahkan melarang segala bentuk penjualan, leasing, serta peminjaman kepemilikan tanah kepada kelompok non-pribumi (Kurniadi, 2019). Selain pelarangan kepemilikan, Kurniadi juga menyatakan bahwa kelompok penduduk non-pribumi (termasuk penduduk etnis Tionghoa) mengalami kesulitan untuk memperoleh status kependudukan yang sah sebagai warga negara Indonesia. Hal ini juga berkaitan dengan peraturan hukum agraria yang menyatakan bahwa kepemilikan tanah di Indonesia hanya diperbolehkan bagi penduduk asli Indonesia.

Tulisan ini berupaya menemukan dan mengelaborasikan faktor-faktor yang menyebabkan diskriminasi hak kepemilikan tanah terhadap penduduk Yogyakarta dari kalangan etnis Tionghoa dapat bertahan setelah melewati berbagai periode serta gejolak politik di Indonesia. Dalam mengkolaborasikan faktor-faktor tersebut, sebelumnya kajian ini telah memahami bahwa terdapat dua aspek yang menjadi garis besar sekaligus limitasi dari faktor-faktor tersebut, yaitu aspek hukum (legal-formal) dan aspek sosiokultural Oleh karenanya, tulisan ini berupaya mendalami faktor-faktor dari aspek hukum (legal-formal) serta aspek sosiokultural yang mengakibatkan diskriminasi tersebut dapat bertahan 
seiring berjalannya waktu. Adapun faktor hukum berkaitan erat dengan berbagai jenis kebijakan resmi yang dikeluarkan oleh pemerintah Yogyakarta serta para pengambil kebijakan terkait. Sementara faktor sosio kultural dikaitkan dengan bagaimana Sultan sebagai pemegang kekuasaan tertinggi di Yogyakarta menggunakan pengaruh politik tradisionalnya untuk melanggengkan kebijakan serta pemahaman diskriminatif tersebut kepada seluruh penduduk Yogyakarta dari waktu ke waktu.

Kajian tulisan ini menggunakan metode kualitatif dalam proses pengumpulan datanya. Metode tersebut meliputi wawancara lapangan dengan empat narasumber ( Kus Sri Antoro, Zaeolus Siput Lokasari, Handoko, dan Willie Sebastian) terkait, serta studi kasus melalui sumber-sumber sekunder, seperti artikel, buku, kajian yang lain, dan kumpulan berita-berita dari sumber online.

\section{KAJIAN LITERATUR}

Perilaku diskriminatif dalam konteks politik dapat diasosiasikan dengan kekuasaan (power). Sebagaimana dielaborasikan oleh Blalock (1961), diskriminasiterutama diskriminasi berbasis ras-merupakan 
ekspresi kekuasaan yang dikeluarkan oleh kelompok/ pihak yang berkuasa/mendominasi terhadap kelompok lain yang lebih kecil/minoritas. Lebih lanjut, kekuasaan yang diekspresikan dalam bentuk diskriminasi tersebut bersumber dari tiga faktor utama. Adapun faktor/ sumber dari kekuasaan tersebut meliputi jumlah (numbers), sumberdaya (resources), dan organisasi sosial (social organization) (Bierstedt, 1950). Dalam praktik diskriminasi, faktor-faktor tersebut berfungsi sebagai kekuatan sosial (social forces) yang dimobilisasi oleh pihak yang berkuasa dalam menjalankan sekaligus melanggengkan praktik-praktik diskriminasi tersebut. Di sisi lain, Bierstedt juga menyatakan bahwa pihakpihak yang mengalami diskriminasi akan terusmenerus diasingkan dari akses atas faktor-faktor sosial tersebut. Hal ini menyebabkan terjadinya situasi yang menguntungkan pihak penguasa/mayoritas dikarenakan faktor-faktor sosial tersebut akan terus tersedia bagi mereka untuk dapat dimobilisasi. Selain itu, hal tersebut mengakibatkan posisi mereka tidak dapat dilawan, bahkan digulingkan oleh kelompok minoritas. Dengan kata lain, selama faktor-faktor sosial tersebut masih berada di pihak penguasa, praktik-praktik diskriminasi sebagai ekspresi kekuasaan akan terus berlangsung. 
Dalam perspektif sosiologis, praktik diskriminasi yang berlangsung di dunia post-civil rights mengalami transformasi ke dalam bentuk yang lebih sulit untuk diidentifikasi daripada sebelumnya. Hal ini dikarenakan praktik diskriminasi telah mengalami proses institusionalisasi yang melampaui serangkaian aturan \& prosedur formal-yang justru memberikan dasar bagi perlakuan yang sama bagi semua kelompok/ golongan-serta menjadi suatu konstruksi sosial yang hanya menguntungkan bagi segelintir pihak. Dengan kata lain, praktik diskriminasi dalam dunia modern mengacu pada konstruksi sosial dari suatu prosedur formal dengan dasar persamaan hak dan kesetaraan, yang dalam pelaksanaannya justru bersifat merugikan bagi kelompok-kelompok tertentu (Pager \& Shepherd, 2008). Sejalan dengan hal tersebut, Pager juga menyatakan bahwa praktik diskriminasi menjadi faktor pendukung terhadap adanya ketidaksetaraan (inequalities) dalam berbagai aspek dalam kehidupan manusia di dunia modern.

Berkaitan dengan konteks topik tulisan ini, salah satu aspek yang menjadi penekanan adalah aspek pertanahan. Dalam sebuah survei yang dilakukan oleh Kementerian Perumahan dan Pembangunan Kota Amerika Serikat pada tahun 2000 hingga 2002, 
ditemukan serangkaian perilaku diskriminatif terhadap kelompok-kelompok kulit hitam, Latin, serta Asia di Amerika dalam aspek pertanahan dan perumahan (Turner \& Ross. L., 2002). Survey tersebut menemukan bentuk-bentuk perilaku diskriminatif, di antaranya pengurangan akses informasi terhadap properti yang ditawarkan, minimnya kesempatan untuk melakukan pembelian properti (lebih diutamakan kepada kelompok kulit putih), dan bantuan finansial (kredit) yang lebih diutamakan untuk kelompok kulit putih.

Selanjutnya, tulisan ini menjabarkan faktor-faktor yang mengakibatkan terjadinya perilaku diskriminatif dalam konteks masyarakat sosial. Mengacu pada teori yang dikemukakan oleh Reskin (2003), diskriminasi dipengaruhi oleh faktor-faktor di tingkat internal individu, organisasi, hingga strukturalsosial (Reskin, 2003). Faktor-faktor tersebut dapat dielaborasikan sebagai berikut.

\section{Internal Individu (Intrapsychic)}

Pada faktor ini, dijelaskan bahwa perilaku diskriminatif timbul dari adanya sifat atau pun kepercayaan dari seorang individu bahwa individu dengan identitas yang berbeda merupakan golongan yang sifatnya inferior dibandingkan dengan individu 
tersebut. Lebih lanjut, sifat yang berkembang di antara individu tersebut menimbulkan apa yang disebut sebagai prejudice terhadap kelompokkelompok individu yang menjadi minoritas dalam suatu tatanan masyarakat. Dengan adanya prejudice dapat menciptakan pola stigmatisasi/stereotip yang berkembang di masyarakat. Sebagai contohnya, asosiasi bahwa kelompok kulit hitam merupakan kelompok masyarakat yang erat dengan kekerasan dan kemiskinan. Dalam kehidupan masyarakat modern, konsep-konsep tersebut berperan dalam menciptakan perilaku diskriminatif yang tumbuh dari dalam masing-masing individu.

\section{Organisasi}

Faktor organisasi bersumber dari pola sifat \& perilaku individu yang berkembang hingga tahap organisasi formal. Tilly mengemukakan, "diskriminasi yang tercipta dari tahap organisasional diakibatkan oleh organisasi yang keanggotaannya terisikan oleh individu-individu yang memiliki perilaku diskriminatif terhadap suatu kelompok" (Tilly, 1998). Dengan demikian, hal ini membuat individu-individu tersebut memegang kendali terhadap pola kebijakan-kebijakan yang dibuat oleh organisasi tersebut, sehingga organisasi tersebut 
mengeluarkan kebijakan yang bersifat diskriminatif. Seiring berjalannya waktu, kebijakan-kebijakan tersebut dapat diterima oleh publik dikarenakan sudah terformalisasi ke dalam aturan-aturan resmi. Hal ini juga diperkuat dengan peran organisasi dalam proses transformasi kebijakan/aturan resmi menjadi praktik perilaku sehari-hari.

\section{Struktural}

Secara garis besar, faktor struktural menggarisbawahi diskriminasi sebagai dinamika yang terjadi antara kelompok mayoritas/dominan dengan kelompok minoritas pada lingkup konteks sosial yang lebih luas (Pager \& Shepherd, 2008). Faktor struktural merupakan gabungan dari perilaku individu yang bersifat diskriminatif terhadap segelintir kelompok, serta didukung oleh tata aturan formal yang lebih berpihak kepada kelompok dominan tersebut. Hal ini membuat kondisi tersebut terus-menerus direproduksi dalam tatanan sosial. Pada tahap lebih lanjut, faktor struktural ini dapat berakibat pada warisan historis pola perilaku, aturan yang diskriminatif, dan menjadi acuan untuk membentuk perilaku juga tata aturan di masa mendatang dengan prinsip diskriminatif yang sama. 
Konsepsi kekuasaan dalam tradisi Jawa menekankan pada kemampuan si penguasa (raja) untuk mempengaruhi pihak lain (rakyat) agar patuh terhadap perintahnya secara sukarela karena pengaruh dari nilai sosio kultural Jawa yang bersifat adikodrati dan tidak membutuhkan legitimasi formal. Menurut Anderson (1977), konsepsi Jawa melihat kekuasaan sebagai entitas riil dan sebagai entitas konkret yang ada di luar diri dari seorang individu. Berdasarkan konsep kosmopolitan, kekuasaan bersifat sentralistis. Kekuasaan berada pada satu tangan raja yang kuat sebagai konsekuensi dari kharisma dan legitimasinya yang bersifat adikodrati yang sumber kekuasaannya berasal dari Tuhan, sehingga segala sumber pendukung kekuasaan bersifat adiduniawi atau gaib dan spiritual (AM, 1992).

Konstruksi teoritis paham kekuasaan Jawa merangkum beberapa hal pokok mengenai konsepsi kekuasaan di Jawa, yaitu raja sebagai pusat kekuatan kosmis dan mistis, peranan wahyu dan ngelmu kasampurnaan, sekaligus sumber-sumber simbolik yang mendukung kekuasaan Jawa. Pertama, raja sebagai pusat kekuasaan kosmid dan mistis mengartikan raja sebagai pusat kekuatan spiritual bagi seluruh kerajaannya, karena hanya rajalah yang dipercaya mampu menyerap kekuatan-kekuatan kosmis dari alam 
sekelilingnya. Konsepsi kosmologis menekankan bahwa jagad ini terdiri dari mikro dan makro kosmos (alam semesta dan dunia manusia), sehingga raja diartikan sebagai penyeleras atau penyeimbamg di antara kedua alam. Kedua, peranan ngelmu kasampurnaan berarti penguasa diharapkan dapat menciptakan stabilitas dalam kerajaan dan pemerintahannya. Selain itu, juga menciptakan keadaan yang harmonis dan selaras dengan dirinya sendiri, masyarakat, dan serasa dengan Tuhan, sehingga dapat mengendalikan hal-hal duniawi yang tidak tampak tetapi mempunyai kekuatan yang dinamis. Ketiga, sumber-sumber simbolik yang mendukung kekuasaan raja diperoleh dengan komunikasi bersama dunia adiduniawi atau supraalam yang tidak tampak, bertapa dan memberikan sesaji ke tempat-tempat yang dianggap sakral (Isbodroini Suyanto-Gunawan, 2005).

Legitimasi penguasa atau raja didapatkan melalui wangsit yang menjadi hal penting bagi seorang penguasa. Wangsit diibaratkan sebagai sebuah benda yang berasal dari langit dan jatuh kepada seorang penguasa sebagai tanda adanya pemindahan kekuasaan. Wangsit yang melekat pada diri seseorang dapat dilihat dari kemampuannya dalam menghimpun kuasa dalam dirinya, menyerap kuasa dari luar, dan mengkonsentrasikan ke dalam dirinya (Anderson, 
1972). Kemudian, feodalisme adalah sistem sosial atau politik yang memberikan kekuasaan yang besar kepada golongan bangsawan. Feodalisme disematkan oleh sejarawan pada sistem politik di Eropa pada abad pertengahan yang menempatkan kalangan ksatria dan kelas bangsawan lainnya (vassal) sebagai penguasa kawasan atau hak tertentu (disebut fiefatau, dalam bahasa latin, feodum) yang ditunjuk oleh monarki (biasanya raja atau lord) (Suparman, 2017).

Pemerintahan Belanda pasca VOC sesudah abad 19 menerapkan sistem pemerintahan yang mempertahankan asas-asas sistem kekuasaan dan sosok budaya yang berpengaruh terhadap keraton Yogyakarta dengan memandang Sultan sebagai lord atau pemilik tanah. Sistem pemerintahan ini menempatkan raja sebagai pemilik tanah kerajaan dengan kekuasaan mutlak. Orang feodal tidak melihat orang dari segi kapabilitas dan kompetensinya, tetapi dari segi asalusul dan "derajat kebangsawananya" (Massholeh, 2015). Karenanya, hal itu menimbulkan nilai pelayanan yang berlebihan kepada penguasa dan terkadang rakyat menjadi pakewuh untuk menentang kebijakan. Hukum ditegakkan atas dasar alat proteksi terhadap kekuasaan, bukan atas dasar keadilan. 
Soeyatno dalam (Supriadi, 2017), stratifikasi sosial feodal masyarakat Jawa terdiri dari:

1. Santono Dalem, yaitu keluarga raja, seperti pangeran, bangsawan yang digolongkan sebagai kelas penguasa.

2. Abdi Dalam, yaitu para pegawai kerajaan.

3. Kawula Dalem, yaitu rakyat.

\section{METODE PENELITIAN}

Metode yang digunakan dalam penelitian ini menggunakan metode kualitatif melalui pengumpulan data dengan melibatkan berbagai sumber informasi (empat wawancara, studi literatur, dan dokumen). Teknik pengumpulan data dilakukan dengan dua cara yakni, primer dan sekunder. Pengumpulan data primer dilakukan dengan cara mewawancarai narasumber yang telah ditetapkan sebelumnya. Dalam penelitian ini, peneliti mewawancarai Zealous Siput Lokasari, Willie Sebastian, Kus Sri Antoro, dan Handoko. Untuk melakukan wawancara, dibuat kesepakatan pertemuan dengan narasumber dalam kurun waktu satu minggu. Sedangkan, pengumpulan data sekunder diperoleh dari berbagai sumber melalui media lainnya, seperti media 
online, kajian pustaka, jurnal, dan beberapa dokumen dari narasumber yang didapatkan saat wawancara.

\section{ASAL MULA KONFLIK AGRARIA DAN PROSES KELUARNYA SURAT INSTRUKSI KEPALA DAERAH}

Diskriminasi rasial dan etnis menurut UndangUndang Nomor 40 Tahun 2008, yaitu segala bentuk pembedaan, pengecualian, pembatasan, atau pemilihan berdasarkan ras dan etnis yang mengakibatkan pencabutan atau pengurangan pengakuan, perolehan, atau pelaksanaan hak asasi manusia. Mengacu dari Undang-Undang tersebut terlihat bahwa sengketa kepemilikan tanah di Yogyakarta termasuk ke dalam diskriminasi rasial dan etnis yang masih berlangsung hingga saat ini. Diskriminasi yang dimaksud adalah pelarangan kepemilikan tanah oleh WNI keturunan, seperti etnis Tionghoa, Arab, dan India. Berdasarkan Undang-Undang Nomor 12 dan 23 Tahun 2006 mengenai kode kewarganegaraan terdapat nomor pembeda untuk menunjukkan status kenegaraan (Willie \& Antoro, 2020). Terdapat 5 kode, Kode 1920 merupakan kode pengenal untuk golongan Warga Negara Indonesia asli yang beragama Islam, tetapi kode ini juga diberikan kepada WNI keturunan (Arab, India, dsb) beragama 
Islam dan sudah lama menetap di Indonesia. Kode 1933 merupakan kode pengenal untuk Warga Negara Indonesia asli yang beragama Nasrani/Kristen. Kode 1917 merupakan kode pengenal untuk Warga Negara Indonesia keturunan Tionghoa apapun agamanya. Kode 1849 merupakan kode pengenal untuk Warga Negara Indonesia keturunan Eropa apapun agamanya. Non STBLD digunakan untuk Warga Negara Indonesia asli yang beragama Budha atau Hindu (Vidyarmoko, 2011). Dengan adanya kode pembeda dalam akta kelahiran menunjukkan bahwa terdapat diskriminasi, khususnya untuk WNI keturunan karena tidak bisa memiliki hak milik atas tanah di Yogyakarta. Larangan WNI keturunan di Yogyakarta dalam kepemilikan tanah dan hanya bisa memiliki Hak Guna Bangunan (HGB) tertera dalam Surat Instruksi Wakil Kepala Daerah (Wagub) DIY No K.898/i/A/1975 tentang Penyeragaman Policy Pemberian Hak Atas Tanah Kepada Seorang WNI NonPribumi yang mengacu pada Undang-Undang Pokok Agraria No. 21 Tahun 1960. Isi dari UU PA adalah "hanya warga negara Indonesia dapat mempunyai hak milik" (Vidyarmoko, 2011).

Selain adanya peraturan tertulis, alasan terjadinya pelarangan dipengaruhi adanya dendam kultural yang dilatarbelakangi oleh sikap etnis Tionghoa dalam 
eksploitasi kalangan pribumi pada masa kolonial Hindia Belanda (Hadi, 2019). Hal ini sejalan dengan latar belakang etnis Tionghoa di Indonesia (Willie \& Siput, 2020), bahwa etnis Tionghoa diklaim sebagai pemberontak pada masa Kolonial. Selain itu, pada masa Kolonial, etnis Tionghoa terkesan dilindungi Kolonial serta memiliki kedudukan ekonomi yang kuat, sementara pribumi yang memiliki kedudukan buruk. Masyarakat Tionghoa dimanfaatkan VOC sebagai rekan bisnis dan mendapat perlakuan istimewa ketimbang kebanyakan masyarakat setempat (Dhani, 2016).

Kebencian terhadap etnis Tionghoa merupakan konstruksi sosial yang dibuat oleh penguasa (Kolonial). Karenanya, diskriminasi yang terjadi sekarang ini masih tergolong sebagai imbas dari masa Kolonial. Pakar Sejarah Universitas Gadjah Mada (UGM), Suhartono berargumen bahwa Surat Instruksi Wakil Kepala Daerah (Wagub) DIY No K.898/i/A/1975 keluar karena titah Sultan (Hadi, 2019). Sejarah pertanahan di Yogyakarta sebelum republik menganut prinsip belong to the king, tanah milik raja. Status tanah milik kerajaan (kesultanan) yang tidak bisa diwariskan oleh pejabat atau abdi dalem. Kepemilikan tanah dengan cara dibagikan kepada pejabat di lingkungan istana namun ketika meninggal, hak milik tanah kembali ke kerajaan. 
Setelah adanya cultuurstelsel, tanah kerajaan disewakan dan hasil persewaan masuk ke kerajaan, mengingat sistem yang diusung adalah belong to the king (Hadi, 2019). Dampak dari adanya peraturan ini, etnis Tionghoa tidak bisa memiliki hak milik atas tanah. Hal ini diperkuat dengan kesaksian beberapa narasumber bahwa ketika membeli tanah, etnis Tionghoa tidak bisa melakukan balik nama dengan status pemilik tanah, mereka hanya bisa mendapat tanah dengan status Hak Guna Bangunan (HGB). Dalam proses membuat Hak Guna Bangunan (HGB) pun etnis Tionghoa harus menandatangani surat dengan sukarela, yang mana sebenarnya mereka tidak melakukannya secara sukarela. Hal ini dilakukan karena apabila etnis Tionghoa menolak, BPN tidak akan memproses surat kepemilikan tanah tersebut (Willie,n2020). Dari sini terlihat jelas bahwa terdapat diskriminasi atas kepemilikan tanah. Hal yang terjadi ini dinilai bertentangan dengan pasal 28 D ayat (1) UUD 1945 yang menyatakan, "Setiap orang berhak atas pengakuan, perlindungan, dan kepastian hukum yang adil serta perlakuan yang sama dihadapan hukum" (Amali, 2019).

Contoh kasus mengenai adanya diskriminasi ras atas tanah, berdasarkan surat hasil pemeriksaan yang dilakukan oleh Ombudsman Republik Indonesia 
Perwakilan DIY, antara lain yaitu Eni Kusumawati yang membeli dua petak tanah milik Junarso di Desa Ngestiharjo, Kabupaten Bantul saat hendak mengajukan peralihan hak milik atas tanah terganjal oleh kantor pertanahan Bantul, Veronika Lindayati yang membeli tanah di daerah Kulon Progo tetapi tidak dapat melakukan balik nama karena kantor pertanahan Kulon Progo menolak, dan Tan Susanto Tanuwijaya yang membeli tanah di Kecamatan Umbulharjo, Yogyakarta tidak diberikan status hak milik. Kemudian, Budi Setyagraha yang mengajukan Perkara Kasasi Tata Usaha Negara kepada Mahkamah Agung atas tanah di Desa Ngestiharjo, Kabupaten Bantul melawan Kepala Kantor BPN Kabupaten Bantul. Dari keempat contoh kasus memiliki kesamaan bahwa mereka tidak bisa diberikan status hak milik karena dianggap sebagai WNI Keturunan (Non-Pribumi). Kemudian status tanah diturunkan dari hak kepemilikan menjadi hak guna bangunan.

Dugaan maladministrasi dalam bentuk pelayanan dan penyimpangan prosedur oleh kantor pertanahan di area DIY dilakukan dengan dalih adanya instruksi Kepala Daerah DIY No. K.898/I/A/1975. Berdasarkan putusan Nomor $13 \mathrm{P} / \mathrm{HUM} / 2015$ yang dikeluarkan oleh Mahkamah Agung, atas perkara penyeragaman 
policy pemberian hak tanah kepada seorang WNI non-pribumi, antara advokat Handoko melawan Gubernur DIY, yang kemudian dimenangkan oleh pihak yang diperkarakan, yaitu Gubernur DIY. Dalam putusan tersebut menyebutkan bahwa adanya prinsip kewenangan keagrariaan berada di tangan gubernur kepala daerah DIY. Hal ini didasarkan oleh UndangUndang Penanaman Modal Dalam Negeri atau PMDN, Nomor 1 Tahun 1967 yang kemudian diganti dengan PMDN Nomor 6 Tahun 1972 tentang, pelimpahan wewenang khususnya DIY. Undang-undang tersebut masih ditangguhkan berlakunya sesuai dengan Keputusan Menteri Dalam Negeri Nomor 92 Tahun 1972. Berdasarkan ketentuan tersebut, maka Gubernur DIY berhak untuk menggunakan instruksi Kepala Daerah DIY No. K 898/I/A/1975. Hal ini berarti sudah sesuai dengan kewenangan atau kedudukan atas urusan keagrariaan. Meskipun sudah diberlakukan sepenuhnya, Undang-Undang Nomor 5 Tahun 1960 tentang peraturan dasar pokok-pokok agraria di DIY, berdasarkan Keppres Nomor 33 Tahun 1984.

Adapun diskriminasi yang tertuang dalam instruksi K 898/I/A/1975 berbunyi, seperti berikut. 
"Sebagaimana diketahui policy Pemerintah Daerah Istimewa Yogyakarta hingga sekarang belum memberikan hak milik atas tanah kepada seorang Warganegara Indonesia non-Pribumi yang memerlukan tanah. Guna penyeragaman policy pemberian hak atas tanah dalam wilayah Daerah Istimewa Yogyakarta kepada seorang Warganegara Indonesia non Pribumi, dengan ini diminta: Apabila ada seorang Warganegara Indonesia non Pribumi membeli tanah hak milik rakyat, hendaknya diproseskan sebagaimana biasa, ialah dengan melalui pelepasan hak, sehingga tanahnya kembali menjadi tanah negara yang dikuasai langsung oleh Pemerintah DIY dan kemudian yang berkepentingan/melepaskan supaya mengajukan permohonan kepada Kepala Daerah DIY untuk mendapatkan sesuatu hak."

Bila mengacu pada UU Nomor 5 Tahun 1960 pada bagian penjelasan umum, disebutkan bahwa perlunya perlindungan bagi golongan warga negara yang lemah terhadap sesama warga negara yang kuat kedudukan ekonominya. Maka, belum atau tidak diberikan hak milik kepada WNI non-pribumi yang merupakan minoritas rakyat DIY karena kebanyakan dari mereka sebagai pelaku ekonomi kuat. Diskriminasi yang dilakukan menurut pendukung adanya instruksi itu bertujuan positif, yaitu mencapai kesetaraan dalam masyarakat. Kemudian affirmative action ini disebut sebagai positive discrimination oleh mereka yang mendukung. 
Dasar hukum yang mengatakan diskriminasi positif atau affirmative policy ini tidak dibenarkan oleh semua kalangan. Hal ini ditandai dengan turunnya surat rekomendasi dari Komnas HAM No 037/R/Mediasi/ VIII/2014 kepada Gubernur DIY dan argumentasinya berisi, antara lain:

1. Affirmative policy merupakan tindakan yang dapat ditempuh guna melindungi kelompok rentan, seperti anak-anak, perempuan, kaum lanjut usia, disabilitas, serta kelompok-kelompok minoritas.

2. Pembatasan/pengurangan hak asasi hanya dapat dilakukan oleh dan berdasarkan undang-undang.

3. Di kenyataan sosial yang ada, tidak seluruhnya keturunan etnis Tionghoa merupakan warga negara yang memiliki kelebihan finansial atau tergolong pemodal kuat.

4. Sikap Pemerintah Provinsi D.I. Yogyakarta melanggar ketentuan yang berkedudukan hukum lebih tinggi dari Instruksi Wakil Gubernur, di antaranya Pasal 5 ayat (3) UU Nomor 39 Tahun 1999 tentang Hak Asasi Manusia, Pasal 6 dan 7 UU Nomor 40 Tahun 2008 tentang penghapusan Diskriminasi Ras dan Etnis, Pasal 28I Ayat (2) 
UUD 1945, Pasal 8 Ayat (1) dan Ayat (2) dan Pasal 21 Ayat (1) UU Nomor 5 Tahun 1960.

Selain itu terdapat surat rekomendasi dari ombudsman RI yang berisi mengenai rekomendasi agar Kantor Pertanahan Kabupaten Bantul, Kabupaten Kulonprogo, dan Kota Yogyakarta segera menindaklanjuti prosedur permohonan peralihan hak atas tanah yang diajukan masyarakat sesuai peraturan perundangan dan tidak ada diskriminatif. Kemudian menyarankan kepada Kantor BPN DIY untuk menyusun petunjuk teknis untuk seluruh Kepala Kantor di DIY sebagai pedoman dalam menindaklanjuti permohonan pendaftaran peralihan hak atas tanah khususnya WNI etnis Tionghoa.

\section{FAKTOR HUKUM DAN SOSIOKULTURAL}

Sampai saat ini, WNI keturunan Tionghoa yang hendak memiliki tanah di DIY hanya bisa mendapat Hak Guna Bangunan atau Hak Pakai tanpa bisa memiliki Sertifikat Hak Milik. Pembatasan kepemilikan tanah bagi etnis Tionghoa ini masih berlangsung bahkan didukung sebagian besar masyarakat DIY. Menjadi menarik melihat lebih jauh mengapa hal ini bisa terjadi dan apa saja alasannya. Pada bagian ini, diungkaplah faktor apa 
saja yang melatarbelakangi kebijakan diskriminatif ini masih berjalan.

Pemberlakuan Undang-Undang No. 13 Tahun 2012 tentang Keistimewaan Daerah Istimewa Yogyakarta menjadi salah satu faktor mengapa tindakan diskriminasi terhadap etnis Tionghoa masih berlaku hingga sekarang. Undang-Undang ini menjadi faktor hukum yang mempengaruhi berlakunya kembali Instruksi Wakil Kepala Daerah Nomor K.898/1975 Tentang pembatasan kepemilikan tanah bagi warga non-pribumi. Melalui Undang-Undang No. 13 Tahun 2012, pemerintah D.I Yogyakarta diberikan kewenangan istimewa dalam menyelenggarakan pemerintahannya. Dalam Pasal 7 Ayat (2) disebutkan Kewenangan Istimewa yang dimiliki D.I Yogyakarta, di antaranya a) tata cara pengisian jabatan, kedudukan, tugas, dan wewenang Gubernur dan Wakil Gubernur; b) kelembagaan Pemerintah Daerah D.I. Yogyakarta, c) kebudayaan, d) pertanahan, dan e) tata ruang. Dalam pasal tersebut disebutkan pertanahan menjadi kewenangan istimewa yang dimiliki D.I Yogyakarta sebagai sebuah daerah dengan otonomi khusus. Kemudian, kewenangan istimewa mengenai pertanahan di D.I Yogyakarta dipertegas dalam Bab $\mathrm{X}$ tentang pertanahan yang terdiri dari Pasal 32 dan 
33 berisi tentang wewenang pengelolaan tanah oleh Kasultanan dan Kadipaten.

Undang-Undang No. 13 Tahun 2012 tentang Keistimewaan Daerah Istimewa Yogyakarta yang telah disahkan di masa pemerintahan Susilo Bambang Yudhoyono sebetulnya tidak mengatur mengenai pembatasan kepemilikan tanah oleh non-pribumi. Tetapi, diterbitkannya Undang-Undang No. 13 Tahun 2012 tentang Keistimewaan Daerah Istimewa Yogyakarta menjadi dasar atau permulaan menguatnya kembali Instruksi Wakil Kepala Daerah Nomor K.898/1975. Penguatan ini bisa dilihat dengan adanya Surat Gubernur No. 593/4811 Tahun 2012 dan Surat Gubernur No. 593/0708 Tahun 2013. Surat Gubernur tersebut berisi instruksi kepada Kepala BPN kanwil DIY untuk mengendalikan setiap permohonan perpanjangan Hak Pakai, HGB, peningkatan Hak serta pengalihan hak atas tanah yang dikuasai pemda DIY (Lestarini, 2018). Selain itu, terdapat pula surat keterangan Pemprov D.I Yogyakarta pada 8 Mei 2012 No. 593/o0531/RO.I/2012 yang menyebutkan, "Instruksi Kepala daerah DIY No. K.898/1975 sampai saat ini masih berlaku dan merupakan affirmative policy yang tujuannya untuk melindungi warga pribumi agar kepemilikan tanah tidak beralih kepada warga atau pemodal yang secara 
finansial memiliki kemampuan lebih atau kuat" (BBC, 2019). Diterbitkannya Undang-Undang No. 13 Tahun 2012 tentang Keistimewaan Daerah Istimewa Yogyakarta telah secara jelas menjadi sebuah faktor hukum berlakunya kembali Instruksi Wakil Kepala Daerah No. K.898/1975 tentang pembatasan kepemilikan tanah oleh non-pribumi. Hal tersebut dikarenakan beberapa surat yang beratas namakan Gubernur dan Pemprov DIY yang mengatur tentang pembatasan kepemilikan tanah kepada non-pribumi diterbitkan setelah UndangUndang Keistimewaan tersebut diberlakukan.

Masyarakat keturunan Tionghoa bukan tanpa protes atau tidak melakukan perjuangan apa pun dengan adanya tindak diskriminasi yang terjadi di DIY. Bapak Handoko seorang advokat keturunan Tionghoa pada tahun 2018 menggugat Gubernur DIY Sri Sultan Hamengkubuwono Xdan Kepala Kanwil BPN DIY karena dianggap melanggar Inpres Nomor 26 Tahun 1998 tentang Menghentikan Penggunaan Istilah Pribumi dan Nonpribumi, Pasal 28 I [2] UUD 1945 Amandemen Keempat, dan Pasal 21 ayat 1 UU Nomor 5 Tahun 1960 tentang Peraturan Dasar Pokok-Pokok Agraria (UU PA) (Putsanra, 2018). Ada alasan kuat mengapa beliau berani menggugat dan memperjuangkan penghentian diskriminasi ini. Alasan beliau menggugat karena adanya keresahan pribadi 
bahwa tidak bisa dibenarkan ada aturan yang rasis di Yogyakarta (Handoko, 2020). Namun, dalam prosesnya gugatan tersebut ditolak oleh hakim Pengadilan Negeri Yogyakarta. Penolakan gugatan tersebut menjadi faktor hukum yang menjadikan diskriminasi atas pembatasan kepemilikan tanah kepada etnis keturunan Tionghoa di DIY masih tetap berjalan sampai saat ini. Hal tersebut dikarenakan menurut Majelis Hakim jika diuji dengan Asas-Asas Umum Pemerintahan yang Baik (AAUPB), maka pemberlakuan instruksi tersebut tidak bertentangan dengan AAUPB karena bertujuan melindungi kepentingan umum, yaitu masyarakat ekonomi lemah (Putsanra, 2018). Selain itu, UndangUndang No. 13 Tahun 2012 tentang Keistimewaan Daerah Istimewa Yogyakarta kembali diangkat sebagai pembenaran berlakunya pembatasan kepemilikan tanah kepada etnis Tionghoa. Persoalan ini berkaitan erat dengan keistimewaan DIY yang memberikan kewenangan istimewa di bidang pertanahan serta menjaga kebudayaan, khususnya keberadaan Kesultanan DIY dan juga menjaga keseimbangan pembangunan di masa yang akan datang (Putsanra, 2018).

Selainfaktorhukum, terdapatpulafaktorsosiokultural yang ada di Keraton Yogyakarta menyebabkan tetap berlakunya pembatasan kepemilikan tanah kepada etnis 
keturunan Tionghoa. Kekuasaan Sultan dan Keraton DIY tidak lepas dari adanya budaya patrimonialisme dalam tubuh birokrasi pemerintahan DIY atau pun Keraton Yogyakarta. Patrimonialisme merujuk pada sentralisasi kekuasaan yang berpusat pada penguasa perseorangan tertentu yang mengakumulasikan kekuasaan, sedangkan yang lain mengidentifikasikan kepentingannya. Penguasa membagikan sumber daya kekuasaannya kepada pihak yang dapat dipercaya dan memiliki pengaruh besar di masyarakat untuk menjaga keberlangsungan dan stabilitas kekuasaannya. Sementara, bagi pihak yang berkepentingan tersebut memiliki aksesibilitas dalam mencari perlindungan politis maupun ekonomi dalam struktur kekuasaan tersebut (Jati, 2012). Faktor sosiokultural ini dipengaruhi oleh adanya istilah Abdi Dalem dalam birokrasi Keraton Yogyakarta. Abdi Dalem merupakan aparatur sipil yang bertugas sebagai pelaksana operasional di setiap organisasi yang dibentuk oleh Sultan (kratonjogja. id, 2016). Ibarat seperti ASN, Abdi Dalem juga memiliki posisi yang istimewa di masyarakat. Dengan menjadi Abdi Dalem, maka seseorang akan memiliki gelar dan pangkat tersendiri sehingga menjadikan derajat mereka di masyarakat terangkat. Hal tersebut menyebabkan Sultan dan Keraton DIY sebagai yang 
memiliki kekuasaan atas segala hal di DIY dikarenakan adanya kesetiaan para Abdi Dalem keraton. Hubungan timbal balik saling menguntungkan antara Sultan DIY dan Abdi Dalem terus berlangsung bahkan dalam praktiknya terdapat pengelompokan Abdi Dalem, yaitu dari kalangan masyarakat biasa (Punakawan) dan Abdi Dalem yang berasal dari TNI, Polri, dan Pegawai Negeri Sipil (PNS) yang diterima dan diangkat sebagai Abdi Dalem (Keprajan) (kratonjogja.id, 2016).

Melalui paparan di atas, nampak bahwa lembaga formal di luar Keraton Yogyakarta juga dilibatkan dalam proses terbentuknya Abdi Dalem Keraton Yogyakarta. Hubungan Raja atau Sultan dengan para Abdi Dalem dipelihara sebagai bentuk pelestarian kebudayaan, tetapi itu berjalan ketika agenda struktural kenegaraan diperlukan (Antoro, 2020). Keadaan ini menyebabkan agenda dan kepentingan pemerintah dan keraton berjalan beriringan dan tidak ada pemisahan yang pasti di antara keduanya. Agenda dan kepentingan keraton pada praktiknya bisa masuk ke dalam agenda dan kepentingan pemerintah meskipun sebenarnya bukan merupakan agenda yang bisa masuk dalam pemerintahan. Sultan mengangkat Abdi Dalem Keprajan yang terdiri dari para pejabat struktural dan penting, seperti Kepala Kantor Wilayah BPN DIY pada 
tahun 2015 Ibu Arie Yuwirin dengan gelar Raden Ajeng Tumenggung Nyi Kisma Manggalawati (Antoro, 2020). Hal ini senada dengan berita di laman detik.com yang memberitakan bahwa sejumlah pejabat pemerintahan di Yogyakarta diangkat menjadi Abdi Dalem Kasultanan Keraton Ngayogyakarta Hadiningrat (detikNews, 2014). Kakanwil Badan Pertanahan Nasional (BPN) DIY Arie Yuwirin juga diangkat sebagai riyo bupati anom dengan menyandang gelar Nyi Riya Kisma Manggalawati (detikNews, 2014). Bahkan dalam persoalan diskriminasi pertanahan di DIY, seorang pejabat Kakanwil BPN DIY diangkat menjadi Abdi Dalem dan ikut menjadi bagian dari kekuasaan Sultan DIY. Seseorang yang diangkat menjadi Abdi Dalem, maka daya kritisnya terhadap ketidakadilan yang disebabkan oleh struktur kekuasaan feodal ini tidak akan muncul (Antoro, 2020). Oleh karena hal tersebut, BPN DIY sebagai lembaga formal yang mengatur tentang pertanahan di DIY melakukan instruksi Sultan tentang pembatasan kepemilikan tanah kepada etnis Tionghoa. Pengangkatan para pejabat struktural penting di DIY menjadi salah satu faktor lain yang dapat dikaitkan dengan tetap adanya diskriminasi terhadap etnis Tionghoa atas kepemilikan tanah di DIY sampai saat ini. 


\section{KEBIJAKAN PERTANAHAN DI DIY DARI SUDUT PANDANG ETNIS TIONGHOA}

Bagi kelompok etnis Tionghoa, kebijakan pertanahan di Yogyakarta ini bersifat diskriminatif dan merugikan mereka karena mereka tidak memiliki akses hak milik atas tanah yang tercantum dalam Undang-undang Pokok Agraria. Alasan dari tidak diperbolehkannya etnis Tionghoa memiliki tanah ini dilatarbelakangi dari Undang-Undang Keistimewaan yang masih melegitimasi aturan lama, yaitu Instruksi Wakil Kepala Daerah DIY No. K.898/I/A/1975 tentang Penyeragaman Policy Pemberian Hak Atas Tanah kepada Seorang WNI Non-Pribumi. Instruksi tersebut mengatakan, tiga golongan yang dilarang untuk memiliki kepemilikan tanah, yaitu, "European" (Eropa, kulit putih); "Vreemde Oosterlingen" (Timur Asing) yang meliputi orang Tionghoa, Arab, India, maupun non-Eropa lainnya (Amali, Duduk Perkara Gugatan Larangan WNI Keturunan Punya Tanah di Jogja, 2019). Maksud dari instruksi tersebut, apabila kaum non-pribumi ingin memiliki tanah, tidak bisa dengan status hak milik. Misal, seorang kaum non-pribumi yang membeli tanah milik rakyat, harus melepas hak miliknya kepada negara lalu statusnya diturunkan menjadi hak guna bangunan atau hak pakai. Oleh karena itu, menurut Siput (2020), 
seorang tokoh Tionghoa, Yogyakarta telah mengalami anomali agraria. Anomali di sini dimaksudkan pada tindakan mengklaim semua tanah masyarakat menjadi tanah milik Kesultanan, dimana Kasultanan bukan lagi sebagai swapraja melainkan sebagai badan hukum.

Selain terkait dengan permasalahan kepemilikan tanah, kaum Tionghoa juga mempermasalahkan penggunaan kata "non-pribumi". Setelah peristiwa 1998, Presiden Habibie mengeluarkan Instruksi Presiden Nomor 26 Tahun 1998 tentang Menghentikan Penggunaan Istilah Pribumi dan Non-Pribumi dalam Semua Perumusan dan Penyelenggaraan Kebijakan, Perencanaan Program, maupun Pelaksanaan Kegiatan Penyelenggaraan Pemerintah. Namun, Pemerintah DIY masih menggunakan istilah tersebut. Karenanya, pada 2010, Willie Sebastian (2020), Ketua Gerakan Anak Negeri Anti Diskriminasi (GRANAD), mengirim surat kepada Presiden Susilo Bambang Yudhoyono, yang kemudian surat tersebut ditanggapi dengan memerintahkan BPN untuk menegur Gubernur Yogyakarta. Namun surat perintah tersebut tidak mendapat balasan dari Gubernur DIY. Atas dasar kegelisahan dan kekecewaan itulah, etnis Tionghoa melampiaskannya dengan (Lestarini, 2018): 
1. Mengirimkan Surat BPN RI No. 4325/016300/XI/2011 (16 November 2011) tentang Penyampaian Pengaduan Masyarakat (Pelarangan Diskriminasi Etnis/Rasial dalam Kebijakan Pertanahan);

2. Mengirimkan Surat Kakanwil BPN DIY No. 0004/300.34/I/2015（2 Januari 2015） perihal Permohonan Informasi (Dukungan terhadap Diskriminasi Etnis/Rasial dalam Kebijakan Pertanahan di DIY);

3. Mengirimkan Surat Rekomendasi kepada Komnas HAM No. 037/R/Mediasi/VIII/2014 (11 Agustus 2014) dan No. 069/R/Mediasi/VII/2015 (7 Agustus 2015), tentang Rekomendasi Terkait dengan Diskriminasi Hak atas Tanah Warga Keturunan Tionghoa di Provinsi DIY.

Selain ketiga surat tersebut, pada 2018, kaum Tionghoa kembali melaporkan kasus ini kepada Ombudsman Republik Indonesia (ORI). Hasil dari laporan tersebut menyatakan bahwa BPN telah melakukan maladministrasi karena menjadikan Instruksi Wakil Kepala Daerah DIY Nomor K.898/I/A/1975 sebagai rujukan kebijakan. Selanjutnya, ORI memberikan saran korektif. Pertama, kepada pihak yang dilaporkan 
agar segera menindaklanjuti permohonan pendaftaran peralihan hak atas tanah yang diajukan para pelapor, sesuai ketentuan peraturan perundang-undangan yang berlaku, tanpa diskriminatif. Kedua, ORI meminta Kepala Kanwil BPN DIY menyusun petunjuk teknik untuk seluruh kepala kantor pertanahan se-DIY sebagai pedoman dalam menindaklanjuti permohonan pendaftaran peralihan hak atas tanah berdasar atas Pasal 45 Ayat (2) dan (3) PP No. 24 Tahun 1997 tentang Pendaftaran Tanah dan peraturan lainnya (Ombudsman Republik Indonesia, 2018). Namun, tutur Willie pada wawancara bersama penulis, menyebutkan bahwa saran yang diberikan oleh ORI tidak dilakukan oleh Pemerintah DIY. Meskipun begitu, Willie dkk tetap memperjuangkan kasus tersebut sampai mereka bisa mendapatkan hak yang seharusnya mereka dapat.

\section{KEBIJAKAN PERTANAHAN DI DIY}

DARI SUDUT PANDANG MASYARAKAT YOGYAKARTA NON-TIONGHOA (YOGYAKARTA, 2020)

Kekuasaan kultural yang telah berada kepada Sultan Yogyakarta dan Kesultanan Yogyakarta telah menjadi sebuah hal yang biasa di DIY. Sebagian besar masyarakat DIY paham betul dengan kekuasaan sultan 
dan cenderung menghormati dan mengabdi. Oleh karenanya, tak jarang kebijakan keraton selalu ditaati dan dipatuhi oleh masyarakat DIY. Tak terkecuali mengenai kebijakan pembatasan tanah bagi warga nonpribumi.

Masyarakat Yogyakarta yang menjadi narasumber sebagian besar mendukung kebijakan ini. Seperti yang telah disebutkan sebelumnya bahwa masyarakat Yogyakarta sangat menghargai, bahkan mengabdi kepada Sultan dan Kesultanan Yogyakarta. Misal nonpribumi boleh punya hak milik pasti banyak orang pribumi yang menjual tanah ke non-pribumi dan lama-lama Yogyakarta akan dikuasai oleh orang nonpribumi. Kelangkaan lahan menjadi alasan bahwa masyarakat Yogyakarta harus didahulukan dalam mempunyai tanah di Yogyakarta. Kemudian, ada juga yang berpendapat bahwa tanah itu merupakan bagian dari kebudayaan seseorang, maka tanah di Yogyakarta harus dipertahankan kepemilikan kepada pribumi atau orang asli Yogyakarta agar kebudayaan tetap lestari. Kebijakan ini juga akan memaksimalkan hak bagi orang pribumi jadi orang Yogyakarta asli bisa memiliki hak lebih karena warga asli sudah lebih dulu bermukim di Yogyakarta. Setidaknya beberapa pendapat pro atas kebijakan ini dari sebagian besar warga Yogyakarta asli 
non-Tionghoa. Sementara, ada juga yang berpendapat bahwa ia tidak setuju dengan kebijakan ini dikarenakan jika seseorang sudah menjadi WNI, maka segala bentuk hak harus didapatkan secara sama rata tanpa membedabedakan hal ini, termasuk wujud pelaksanaan HAM di Indonesia.

\section{KESIMPULAN}

Faktor-faktor yang berperan dalam melanggengkan diskriminasi hak kepemilikan tanah terhadap penduduk etnis Tionghoa di wilayah Yogyakarta antara lain faktor aturan legal formal dan pemahaman sosiokultural.

\section{Aturan Legal Formal}

Pemerintah Daerah Istimewa Yogyakarta melegitimasi aturan lama, yaitu Instruksi Wakil Kepala Daerah DIY No. K.898/I/A/1975 tentang Penyeragaman Policy Pemberian Hak Atas Tanah kepada Seorang WNI Non-Pribumi yang mengacu pada Undang-Undang Pokok Agraria No. 21 Tahun 1960. Isi dari UU PA itu adalah "hanya warga negara Indonesia dapat mempunyai hak milik. Dalam Instruksi 1975, tiga golongan warga nonpribumi yang dilarang punya kepemilikan tanah, yakni Europeanen (Eropa, kulit putih), Vreemde Oosterlingen (Timur Asing) yang meliputi orang Tionghoa, Arab, 
India, maupun non-Eropa lain. Instruksi 898/1975 tersebut melarang WNI keturunan Etnis Tionghoa di Yogyakarta untuk memiliki hak milik atas tanah. Pun keputusan menteri dalam negeri No. 92 Tahun 1972 turut menunjukkan bahwa WNI keturunan etnis Tionghoa hanya diberi Hak Guna Bangunan, Hak Pakai, dan Hak Guna Usaha. Sehingga berdasarkan ketentuan tersebut, Gubernur DIY berhak menggunakan instruksi Kepala Daerah DIY No. K 898/I/A/1975. Instruksi 1975 juga diadopsi lagi ke dalam UU Nomor 13 Tahun 2012 tentang Keistimewaan Daerah Istimewa Yogyakarta, merujuk pada Pasal 7 Ayat 2, DIY mempunyai kewenangan dalam urusan keistimewaan yang meliputi pertanahan sehingga secara tidak langsung DIY mempunyai legitimasi untuk mengatur tanahnya, seperti Sultan Ground, Pakualaman Ground maupun tanah di luar itu.

Undang-Undang keistimewaan DIY pada dasarnya tidak bertentangan dengan UUD NRI 1945, UU Keistimewaan lahir karena adanya Pasal 18B, khususnya yang Ayat (1) UUD NKRI 1945, selain Pasal 5 ayat (1), Pasal 18 A, dan Pasal 20 Undang-Undang Dasar Negara Republik Indonesia Tahun 1975, serta UndangUndang Nomor 3 Tahun 1950. Undang-Undang tersebut diciptakan dengan "mengingat" sebagai dasar hukum Undang-Undang terkait dan terdapat 
bagian "menimbang" sebagai konsiderans/landasan pertimbangan dari aspek filosofis, dan lain sebagainya. Selain itu, undang-undang keistimewaan sudah mengacu pada ketentuan UUD NKRI 1945 sebagaimana mestinya. Karena asas lex superior derogat legi inferiori pun, menyatakan peraturan yang lebih tinggi akan mengalahkan atau mengesampingkan peraturan yang lebih rendah, dimana peraturan di bawah UUD NRI 1945 tidak boleh bertentangan dan harus mengacu terhadap UUD NRI 1945.

\section{Faktor Sosiokultural}

Konsepsi kekuasaan dalam tradisi Jawa menekankan pada kemampuan raja untuk mempengaruhi rakyat agar patuh terhadap perintahnya secara sukarela karena pengaruh dari nilai sosio kultural Jawa yang bersifat adikodrati dan tidak membutuhkan legitimasi formal. Selain itu, faktor feodalisme yang memberikan kekuasaan sosial dan politik yang besar kepada golongan bangsawan. Orang feodal tidak melihat orang dari segi kapabilitas dan kompetensinya, tetapi dari segi asal-usul dan derajat kebangsawan. Karenanya, menimbulkan nilai pelayanan yang berlebihan kepada penguasa dan terkadang rakyat menjadi pekewuh untuk menentang kebijakan. Hukum ditegakkan atas dasar alat proteksi terhadap kekuasaan, bukan atas dasar keadilan. 


\section{REFERENSI}

AM, S. (1992). Konsep Kekuasaan dalam Tradisi Budaya Jawa. Jurnal Cakrawala Pendidikan, 81-93.

Amali, Z. (2019). Duduk Perkara Gugatan Larangan WNI Keturunan Punya Tanah di Jogja, https://tirto.id/ duduk-perkara-gugatan-larangan-wni-keturunanpunya-tanah-di-jogja-elgk.

Anderson, B. (1972). The Idea of Power in Javanese Culture. New York: Cornell University Press.

BPS, D. (2018). Jumlah Populasi di Wilayah DIY.

Isbodroini Suyanto-Gunawan. (2005). Antropologi Indonesia. Jurnal Antropologi Indonesia, 207-218.

KBBI.(2016).dis.kre.si/diskrèsi/.https://kbbi.kemdikbud. go.id/entri/diskresi

Kusumasari, D. (2012). Masalah Hak WNI Keturunan Tionghoa untuk Memiliki Tanah di Yogyakarta. https://www.hukumonline.com/klinik/detail/ ulasan/lt4faoa5a5eof6o/-ask-mohon-pencerahanatas-surat-gubernur-diy-no-k-898-1-a-1975.

Lestarini, R. (2018). Kebijakan Pertanahan Bagi WNI Keturunan Tionghoa di Yogyakarta; Diskriminasi atau Diskriminasi Positif. Jurnal Hukum \& Pembangunan, 44-63. 
Massholeh, M. A. (2015). "Feodalisme": Jurus Ampuh Kolonialisasi Hindia Belanda". Sejarah Indonesia Modern.

Ombudsman Republik Indonesia. (2018). Tionghoa Berhak Punya Tanah SHM. https://ombudsman.go.id/ perwakilan/news/r/pwk--tionghoa-berhak-punyatanah-shm.

Purwadi. (2012). Konsep Kekuasaan Jawa menurut Serat Nitipraja. http://staffnew. uny.ac.id/upload/132309869/penelitian/ KONSEP+KEKUASAAN + JAWA+ MENURUTSERAT-NITIPRAJA.pdf.

Putsanra, D. V. (2018). Hakim Tolak Gugatan Terhadap Larangan Tionghoa Punya Tanah di Yogya. https:// tirto.id/hakim-tolak-gugatan-terhadap-larangantionghoa-punya-tanah-di-yogya-cE63.

Redaksi Indonesia. (2019). Tafsir Jawa terhadap Kuasa dan Kekuasaan. https://www.indonesia.go.id/ ragam/budaya/kebudayaan/tafsir-jawa-terhadapkuasa-dan-kekuasaan.

Suparman, M. (2017). Feodalisme dalam Pemerintahan Dinasti. https://www.kompasiana.com/ mamanpelita/5918f292759373feo48b4568/ feodalisme-dalam-pemerintahan-dinasti 


\section{SUMBER WAWANCARA}

Sda. Antoro, K. S. Hasil Wawancara Pribadi: 11 Maret 2020, Yogyakarta

Sda. Handoko. Hasil Wawancara Pribadi: Februari 2020, Yogyakarta

Sda. Sebastian, W. Hasil Wawancara Pribadi: Maret 2020, Yogyakarta

Sda. Siput, Z. Hasil Wawancara Pribadi: Maret 2020, Yogyakarta

Sda. Yogyakarta, M. (2020). Hasil Wawancara Pribadi: Maret 2020, Yogyakarta

\section{DOKUMEN TAMBAHAN}

Instruksi Wakil Kepala Daerah (Wagub) DIY No. K.898/ i/A/1975 tentang Penyeragaman Policy Pemberian Hak Atas Tanah kepada Seorang WNI Non-Pribumi.

Surat Rekomendasi KOMNAS HAM No. 037/R/Mediasi/ VIII/2014 kepada Gubernur DIY.

Surat Putusan Mahkamah Agung RI No. 28/K/TUN./200 tentang Perkara Kasasi Tata Usaha Negara. 